\title{
Benthic microalgal production in Onslow Bay, North Carolina, USA
}

\author{
Lawrence B. Cahoon ${ }^{1}$, Jacob E. Cooke ${ }^{2}$ \\ ${ }^{1}$ Department of Biological Sciences, UNC Wilmington, Wilmington, North Carolina 28403, USA \\ ${ }^{2}$ Department of Botany, North Carolina State University, Raleigh, North Carolina 27695, USA
}

\begin{abstract}
Benthic microalgal production and sediment respiration were measured in situ at 8 locations in Onslow Bay, a portion of the North Carolina continental shelf, between 1984 and 1989, by measuring changes in dissolved oxygen concentrations inside clear and opaque benthic chambers placed by divers. Measurements were also made of water column productivity, phytoplankton biomass, benthic microalgal biomass, light flux, and temperature. Benthic production and respiration were measured from March through October at locations ranging from 14.6 to $41 \mathrm{~m}$ deep. Gross benthic microalgal production averaged $24.9 \mathrm{mg} \mathrm{C} \mathrm{m}^{-2} \mathrm{~h}^{-1}$, compared to average integrated water column production of $27.4 \mathrm{mg} \mathrm{C} \mathrm{m} \mathrm{Ch}^{-2} \mathrm{~h}^{-1}$ Sediment respiration rates averaged $18.1 \mathrm{mg} \mathrm{C} \mathrm{m}^{-2} \mathrm{~h}^{-1}$, Benthic microalgal biomass averaged $36.4 \mathrm{mg} \mathrm{chl} \mathrm{a} \mathrm{m} \mathrm{m}^{-2}$, and always exceeded integrated phytoplankton.

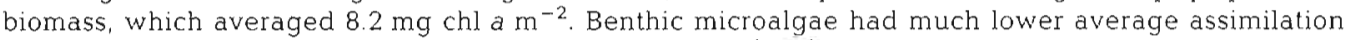
numbers than phytoplankton $\left(0.8\right.$ vs $5.2 \mathrm{mg} \mathrm{C}\left(\mathrm{mg} \mathrm{chl} \mathrm{a}^{-1} \mathrm{~h}^{-1}\right)$. Benthic microalgae make a significant contribution to total shelf production in Onslow Bay. Open sand bottom habitats in this ecosystem must now be viewed as productive, rather than relatively barren.
\end{abstract}

\section{INTRODUCTION}

Benthic microalgae have been shown to be important primary producers in a wide variety of shallow habitats. Most studies of benthic microalgal production have been done in estuaries and intertidal zones. Annual productivity values as high as $892 \mathrm{~g} \mathrm{C} \mathrm{m}^{-2}$ and hourly productivity rates up to $800 \mathrm{mg} \mathrm{C} \mathrm{m}^{-2}$ have been reported (Grontved 1962, Hargrave et al. 1983). The importance of benthic microalgae, particularly in estuarine ecosystems, has therefore been widely recognized (e.g. Cadee \& Hegeman 1977, Varela \& Penas 1985, Lukatelich \& McComb 1986).

Subtidal benthic microalgal production has also been measured in a number of nearshore locations, such as the Oresund in Denmark (Gargas 1970) and the coast of the Chukchi Sea (Matheke \& Horner 1974). A few studies have shown benthic microalgal production to be significant in shallow coral reef habitats (Bunt et al. 1972, Sournia 1976). For the most part, however, there has been little attention directed to benthic microalgal production in continental shelf ecosystems.

Several lines of evidence suggest that benthic microalgal production might be important in the continental shelf ecosystem of North Carolina. Benthic macroalgae are found on hard substrates out to and beyond the shelf break at $55 \mathrm{~m}$ (Schneider 1976), indicating that light and nutrient availability at the shelf bottom do not substantially limit these primary producers. Cahoon et al. (19.90) found that viable chlorophyll a occurred in sediments across the continental shelf in Onslow Bay, North Carolina, and into shallow ( $\leq 285 \mathrm{~m}$ ) continental slope sediments. Concentrations of chlorophyll $a$ and ATP, a measure of living biomass, were significantly and positively correlated in these sediment samples. Comparisons showed that benthic chlorophyll a almost always exceeded integrated water column chlorophyll $a$, and that as much as $80 \%$ of the chlorophyll $a$ in Onslow Bay was associated with the sediment. Cahoon et al. (1990) concluded that settling of phytoplankton was an insufficient explanation for the presence of so much chlorophyll in the sediments of this erosional environment. An examination of the taxonomic composition of the microalgae associated with the sediments in Onslow Bay showed that pennate diatoms dominated the benthic microflora, which was distinct from the phytoplankton assemblage in the overlying waters but much more similar to the littoral diatom flora described by Hustedt (1955) from Onslow Bay (L. B. Cahoon \& R. A. Laws unpubl.). These observations 
suggested that a productive benthic microflora occurs across Onslow Bay, and that its productivity might be significant in comparison to that of the phytoplankton in the overlying water column.

This report describes the results of a study of benthic microalgal biomass and production in Onslow Bay during the period 1984 to 1989 . Benthic microalgal biomass and production were measured in situ at several locations in the inner and mid-shelf regions of Onslow Bay. Concurrent measurements of phytoplankton biomass and production were made at these locations, along with measurements of light flux to the bottom and nutrient fluxes from the sediments.

\section{METHODS AND MATERIALS}

Study sites. Onslow Bay is one of several open bays bounded by the Carolina capes at the northern end of the southeastern U.S. continental shelf, also known as the South Atlantic Bight (SAB) (Fig. 1). The seaward boundary of Onslow Bay is formed by the Gulf Stream near the shelf break. The continental shelf in Onsiow Bay is ca 60 to $110 \mathrm{~km}$ wide and is relatively shallow, breaking at ca $55 \mathrm{~m}$ (Menzies et al. 1966). Onslow Bay frequently experiences subsurface intrusions of slope water associated with upwelling events at the shelf break (Blanton et al. 1981). These intrusions are thought to provide significant inputs of 'new nitrogen' to the shelf ecosystem, with significant effects on productivity (Paffenhöfer et al. 1980, Hanson et al. 1981) Onslow Bay receives relatively little freshwater input in comparison to other portions of the $\mathrm{SAB}$, particularly the Georgia Bight (Atkinson et al. 1978, 1980, Blanton \& Pietrafesa 1978, Singer et al. 1980).

Eight sites in southeastern Onslow Bay ranging in depth from 14.6 to $41 \mathrm{~m}$ were visited during this study (Fig. 1). Several of these sites were associated with limestone outcrops ('5 mile', '23 mile', 'Frying Pan'), several were near artificial reefs (' 3 mile', 'Tugs', '18 mile'), and the remainder were on open sandy bottom ('6 mile', 'Deep').

Benthic microalgal production. Benthic microalgal production was measured in situ at the Onslow Bay sites during the period 1984 to 1989 . Measurement of benthic microalgal production and associated benthic and near-bottom sampling were conducted by SCUBA divers using air and/or NOAA NITROX, or by surfacesupplied air divers. Diving support and supervision was provided by the NOAA National Undersea Research Center at UNC Wilmington (NURC-UNCW).

Benthic microalgal produciun was estimated $b_{y}$ measuring changes in dissolved oxygen concentrations inside clear and opaque benthic chambers placed on the bottom by divers in the morning and retrieved in the afternoon. In situ incubations were used to avoid the substantial disruption of the sediment-water interface inherent in the use of sediment cores returned to

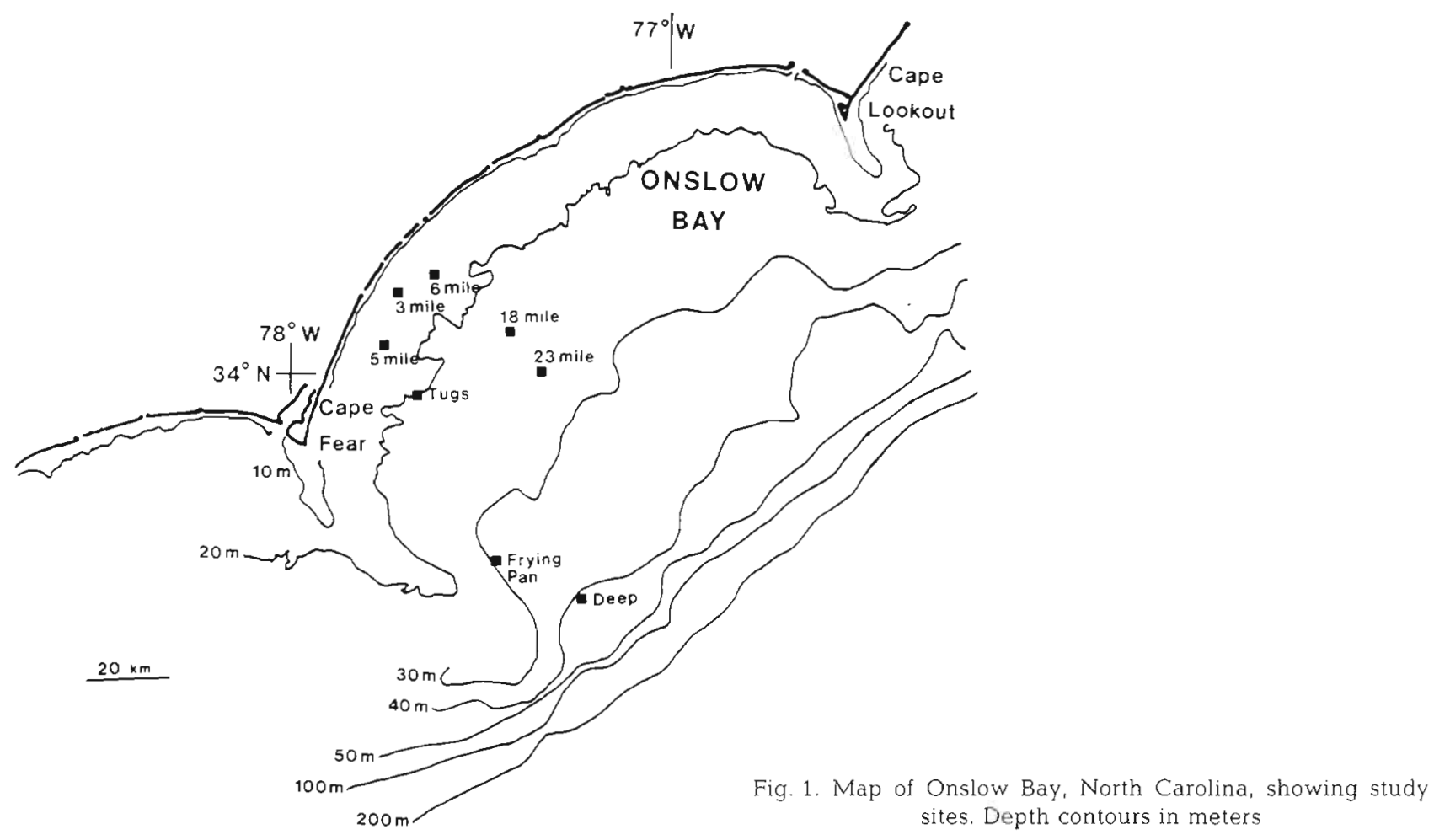


the laboratory, and to permit production and respiration to occur under natural light and temperature conditions. The dissolved oxygen change method was chosen in preference to the ${ }^{14} \mathrm{C}$ method to avoid the difficulty of determining total inorganic carbon in the water at the sediment-water interface under natural conditions (Revsbech et al. 1981). Early results showed that a 6 to 8 h incubation was sufficient to yield statistically significant changes in dissolved oxygen concentrations inside the benthic chambers in most situations. In practice only 2 incubations exceeded 8 h duration.

The benthic chambers used in microalgal production determinations were made of clear plastic domes of $30 \mathrm{~cm}$ diameter (Cahoon 1988). These domes transmitted ca $85 \%$ of photosynthetically active radiation (PAR). Thus, production estimates generated by this method are probably somewhat low if light flux limits benthic microalgal production. Dark chambers were constructed of the same domes by painting the outside with $>4$ coats of flat black latex paint. Stirring of the contents of the domes was provided by a whirling cup rotor device (Cahoon 1988).

A typical microalgal production measurement was begun by placing 4 clear and 4 opaque chambers alternately on a sand bottom devoid of all macrophytes and hard substrates that might support macrophyte growth. Visible burrows and macrofauna were also avoided. The domes were emplaced with care to avoid disturbance of the sediment. Whirling cup rotors were then attached and sealed in place with silicone sealer. Water samples were withdrawn from each chamber with a $50 \mathrm{ml}$ plastic syringe after flushing the syringe 2 to 3 times to stir the chamber contents. Water samples for nutrient analyses were then withdrawn with another $50 \mathrm{ml}$ syringe (for nitrite-nitrate, phosphate, and silicate) and with a $10 \mathrm{ml}$ syringe (for ammonium) for a study of nutrient flux rates. Results of this study will be reported elsewhere. Temperature was measured with a hand-held thermometer at the beginning of each incubation. After a suitable incubation period, usually dictated by surface decompression intervals for the dive team, final sets of dissolved oxygen and nutrient samples were taken. Typical incubations commenced at ca 09:00 h and were ended at ca 16:00 h.

Dissolved oxygen was measured by the Winkler technique (Strickland \& Parsons 1972). From 1984 to 1988 water samples in the syringes were fixed after return to the surface (usually $<10$ min after sampling). Concern that dissolved oxygen might degas from saturated samples brought rapidly to the surface prompted a comparison of the results of fixing dissolved oxygen samples at the bottom immediately after withdrawal from the chambers vs fixing after return to the surface. Although the comparison showed no significant effect, in 1988 and 1989 all samples were fixed on the bottom immediately after withdrawal from the chambers. Winkler analyses were completed within $12 \mathrm{~h}$ on all samples.

Net benthic primary production was calculated by determining dissolved oxygen concentrations in each clear chamber as mmol oxygen $1^{-1}$ using the formula for non-standard sample volumes (Strickland \& Parsons 1972, p. 24) and then applying the following formula:

$$
\mathrm{NBPP}=\left(\left([\mathrm{DO}] t_{2}-[\mathrm{DO}] t_{1}\right) \times V \times 12\right) /(\mathrm{PQ} \times H \times A)
$$

where $\mathrm{NBPP}=$ net benthic primary production in $\mathrm{mg} \mathrm{C}$ $\mathrm{m}^{-2} \mathrm{~h}^{-1} ;$ [DO]t $t_{2}=$ dissolved oxygen concentration in mmol $l^{-1}$ at the end of an incubation; [DO] $t_{1}=$ oxygen concentration at the beginning of an incubation; $V=$ volume of the benthic chambers $(3.51) ; 12=$ the atomic weight of carbon; $\mathrm{PQ}=$ photosynthetic quotient $(\mathrm{mol}$ $\mathrm{O}_{2}$ evolved $\mathrm{mol}^{-1} \mathrm{C}$ fixed; 1.2 is used here; Strickland \& Parsons 1972); $H=$ length of an incubation in hours; and $A=$ area under a benthic chamber $\left(0.071 \mathrm{~m}^{2}\right)$.

Values for sediment respiration were calculated similarly using oxygen concentration data from each dark chamber and the following formula:

$$
\mathrm{RESP}=\left(\left([\mathrm{DO}] t_{1}-[\mathrm{DO}] t_{2}\right) \times V \times 12 \times \mathrm{RQ}\right) /(H \times A)
$$

where RESP = benthic oxygen consumption (the sum of biological respiration and chemical oxygen demand; Pamatmat 1971) in mg $\mathrm{C} \mathrm{m}^{-2} \mathrm{~h}^{-1} ; \mathrm{RQ}=$ respiratory quotient (mol C respired mol ${ }^{-1} \mathrm{O}_{2}$ consumed; 1.0 is used here; Strickland \& Parsons 1972); and the other parameters are as above.

Gross benthic production for each field day's measurements was calculated by summing respiration and net production. Gross production is a better measure of microalgal growth than net production, because the chamber incubation measurements necessarily include the respiratory $\mathrm{C}$ consumption of the abundant sediment-associated bacteria, meiofauna, macroinfauna, and demersal zooplankton.

Microalgal biomass. Sediment samples for analysis of benthic microalgal biomass were collected concurrently with initial placement of the chambers, beginning in 1985. These samples were taken with a $1 \mathrm{~cm}$ diameter hand-held coring tube immediately adjacent to each benthic chamber. Cores were taken to depths just beyond the visible redox gradient in the sediment, and minimally $3 \mathrm{~cm}$. Sediment samples collected in this way were placed in $15 \mathrm{ml}$ plastic screw-cap tubes, capped, and returned to the surface, where they were allowed to settle and the supernatant water was decanted carefully. Microscopic observation and prior analysis of sediment sampling results showed that most of the benthic microalgae were attached to the sediment in the top few mm of sediment. Sediment samples were then frozen at $-4{ }^{\circ} \mathrm{C}$ to await later analysis.

Benthic microalgal biomass was estimated as 
chlorophyll a according to Whitney \& Darley (1979). This spectrophotometric method employs partitioning of a $90 \%$ acetone pigment extract with hexane to eliminate interference from degraded pigments that are common in sediment samples. Reagent grade solvents were used throughout the procedure. Chloro-

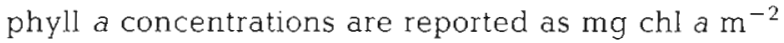

Phytoplankton production and biomass. Primary production by phytoplankton was measured concurrently with benthic microalgal production during the period April 1985 through June 1988, using the ${ }^{14} \mathrm{C}$ light/dark bottle method. Seawater was collected at the surface and bottom and at each $10 \mathrm{~m}$ interval from the surface in a van Dorn bottle. One set of 3 clear and 2 opaque (foil-wrapped) $250 \mathrm{ml}$ bottles was filled with water from each depth, inoculated with a ${ }^{14} \mathrm{C}$-labeled bicarbonate solution ( 1 to $2 \mu \mathrm{Ci}$ total activity), and suspended from a buoy line at the corresponding depth for the duration of a 6 to $8 \mathrm{~h}$ incubation period. Following retrieval, the contents of each bottle were filtered through a $25 \mathrm{~mm}$ Gelman A/E glass fiber filter and rinsed with filtered seawater. Each filter was placed in a scintillation vial containing a $10 \mathrm{ml}$ aliquot of Ecoscint scintillation cocktail. Subsequent counts of these samples on an LKB RackBeta counter were automatically corrected for quench, and external standard counts were used to calculate dpm for each sample. Estimates of total activity added to each bottle were obtained from similar counts of $1 \mathrm{ml}$ aliquots taken from each incubation bottle prior to filtration. Total inorganic carbon concentrations in the seawater samples were calculated from alkalinity determinations according to Parsons et al. (1984). Primary production by phytoplankton was estimated as follows:

$$
P P=\left[\left(\mathrm{dpm}_{\mathrm{L}} / \mathrm{dpm_{ \textrm {T } } ) - ( \mathrm { dpm } _ { \mathrm { D } } / \mathrm { dpm } \mathrm { m } _ { \mathrm { T } } ) ] \times}\right.\right.
$$

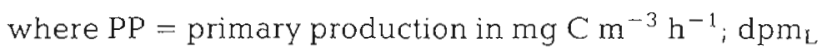
$=$ corrected counts in each light bottle; $\mathrm{dpm}_{\mathrm{D}}=$ corrected counts in each dark bottle; $d p m_{\Upsilon}=$ total corrected counts added to each bottle; $1.06=$ the ${ }^{14} \mathrm{C} /{ }^{12} \mathrm{C}$ discrimination factor; TIC = total inorganic carbon in $\mathrm{mg} \mathrm{C} \mathrm{m}{ }^{-3}$; and $H=$ duration of the incubation in $\mathrm{h}$. Phytoplankton production values were integrated over the depth of the water column to yield estimates of total water column production.

Phytoplankton biomass was measured as chlorophyll a in the same water samples collected for primary production measurements, according to the standard fluorometric technique (Parsons et al. 1984). Triplicate $100 \mathrm{ml}$ samples were filtered through Gelman $\mathrm{A} / \mathrm{E}$ glass fiber filters and stored at $-4{ }^{\circ} \mathrm{C}$ prior to extraction for $24 \mathrm{~h}$ in $90 \%$ acetone and measurement of fluorescence on a Turner Model 111 filter fluorometer fitted with Corning 5-60 excitation and 2-64 emission filters.
The fluorometer was calibrated with chlorophyll a extracts from cultured coastal phytoplankton using the spectrophotometric SCOR-UNESCO method (Parsons et al. 1984).

Light flux. The flux of PAR to the bottom was measured around solar noon during benthic production incubations from September 1984 through June 1988. A LiCor LI-193S spherical quantum sensor interfaced with a LiCor LI-550B integrator or LI-1000 DataLogger was used for these measurements, sometimes in conjunction with the use of a Secchi disk. Quantum sensor readings were taken as close to the bottom as possible. The quantum sensor and Secchi disk gave identical values for the light extinction coefficient, $k$, in the surface layers in direct comparisons in 1984.

\section{RESULTS}

Most (20/29) of the benthic production measurements reported here were made at midshelf locations (18 mile, 23 mile, Frying Pan; Table 1). Eight of the other 9 measurements were made at inmei shelf locations (3 mile, 5 mile, 6 mile, Tugs). The other location (Deep), visited once at $41 \mathrm{~m}$ depth, represents approximately the depth limit for our use of wet diving. The depth range spanned by these sampling locations corresponds to the range occupied by approximately three quarters of the total shelf area (Fig. 1).

Most of the measurements reported here were made during the summer months, when weather and sea conditions were more favorable for wet diving operations (Table 1). However, measurements of benthic processes were also made in early spring (March and April) and in fall (September and October).

Light data indicated that the waters at our Onslow Bay study sites were either clear enough or shallow enough to support relatively high light flux $(>1 \%$ surface incident PAR) to the bottom most of the time (Table 1). Average quantum flux to the bottom at or near solar noon was $115 \pm 81 \mu \mathrm{E} \mathrm{m}^{-2} \mathrm{~s}^{-1}$ and ranged from 11 on a cloudy day to a high of 244 at our study sites.

Storm events that precluded diving might be expected to cause resuspension of benthic microalgae and increased turbidity, thus diminishing benthic microalgal production. However, diver observations and our biomass and production data indicate that only the strongest storms had much effect on the benthic microflora. We frequently sampled 1 to $2 \mathrm{~d}$ after northeast wind events with wind speeds up to 35 knots $\left(18 \mathrm{~m} \mathrm{~s}^{-1}\right)$ and seas up to $3-4 \mathrm{~m}$ without observing subsequent disruption of easily visible microalgae patches on the bottom or lower-than-average benthic production, e.g. in June and October 1988. Tropical storms and hurri- 
Table 1. Characteristics of sampling dates and study sites in Onslow Bay, North Carolina, 1984 to 1989. Sites as in Fig. 1 ; depths in meters; $k$ : light extinction coefficient; $T$. bottom temperature, ${ }^{\circ} \mathrm{C}_{i}-$; no data taken

\begin{tabular}{|c|c|c|c|c|}
\hline Site & Date & Depth & $k$ & T \\
\hline 23 mile & 22 Aug 1989 & 33 & -- & 26 \\
\hline 23 mile & 18 Aug 1989 & 33 & - & 26 \\
\hline 23 mile & 16 Aug 1989 & 28.6 & - & 26 \\
\hline 23 mile & 12 Aug 1989 & 28.6 & - & 26.5 \\
\hline 5 mile & 4 Aug 1989 & 18 & - & 26 \\
\hline 5 mile & 3 Aug 1989 & 18 & - & 26 \\
\hline 5 mile & 2 Aug 1989 & 18 & - & 26 \\
\hline 18 mile & 15 Oct 1988 & 26.8 & - & 21.8 \\
\hline 18 mile & $14 \mathrm{Oct} 1988$ & 26.8 & - & 22 \\
\hline 23 mile & $8 \mathrm{Jul} 1988$ & 28 & - & 24 \\
\hline 23 mile & 14 Jun 1988 & 26.8 & - & 22 \\
\hline 23 mile & 13 Jun 1988 & 28 & - & 21.5 \\
\hline 23 mile & 12 Jun 1988 & 28 & 0.086 & 21.5 \\
\hline Tugs & 5 Mar 1986 & 17.7 & 0.176 & 10.2 \\
\hline 3 mile & 4 Mar 1986 & 14.6 & 0.242 & 9.4 \\
\hline 23 mile & 25 Sep 1985 & 32 & - & 27 \\
\hline Frying Pan & 9 Sep 1985 & 31 & 0.117 & 24.5 \\
\hline Frying Pan & 8 Sep 1985 & 27.3 & 0.126 & 24.5 \\
\hline Frying Pan & 7 Sep 1985 & 29 & 0.103 & 24.5 \\
\hline Frying Pan & 6 Sep 1985 & 29 & 0.074 & 24.5 \\
\hline Frying Pan & $31 \mathrm{Jul} 1985$ & 29.2 & 0.072 & 25.4 \\
\hline Frying Pan & $30 \mathrm{Jul} \quad 1985$ & 29.9 & 0.085 & 26.4 \\
\hline Frying Pan & 29 Jul 1985 & 30.5 & 0.076 & 26 \\
\hline 3 mile & $23 \mathrm{Apr} 1985$ & 17.7 & 0.215 & 16.8 \\
\hline Deep & $21 \mathrm{Apr} 1985$ & 41 & 0.079 & 19.6 \\
\hline 23 mile & $19 \mathrm{Apr} 1985$ & 31.7 & 0.104 & 17.6 \\
\hline 23 mile & 26 Sep 1984 & 28 & 0.185 & 25.2 \\
\hline 6 mile & 16 Aug 1984 & 18.3 & - & 23.8 \\
\hline 3 mile & $26 \mathrm{Jul} 1984$ & 16 & - & 25.3 \\
\hline
\end{tabular}

canes were a significant exception to this pattern. The July 1985 measurements at Frying Pan were made immediately after Tropical Storm Bob passed within $110 \mathrm{~km}$, and showed a rapid increase in benthic production within 3 d (29 to 31 July; Table 2). The 26 Sep 1984 measurement was made $2 \mathrm{wk}$ after Hurricane Diana stalled directly over the 23 mile site for $24 \mathrm{~h}$. In this case benthic production was completely stopped, bottom visibility at this site was $<2 \mathrm{~m}$, and substantial damage to the macroflora and macrofauna communities was evident. Within 6 w $\mathbf{k}$, however, dense patches of benthic microalgae were observed at this location (Plate 1 in Cahoon et al. 1990).

Cloud cover had a significant effect on light flux to the bottom and, consequently, on benthic primary production. As noted above, cloud cover would reduce light flux to the bottom by an order of magnitude. Days with $100 \%$ cloud cover, e.g. 29 Jul 1985, 8 Sep 1985, 9 Sep 1985, and 12 Aug 1989, had much lower gross primary production rates than immediately preceding or following sunny or partially cloudy days (Table 2).
The effects of cloudy days are averaged into our calculations of average production; together with the effects of strong storms and seasonality, these effects are responsible for much of the variability in the production data.

Gross benthic production equalled or exceeded benthic respiration 22 out of 29 times (Table 2). Average gross benthic production, including all seasons and post-storm measurements, was $24.9 \mathrm{mg} \mathrm{C} \mathrm{m}^{-2} \mathrm{~h}^{-1}$. Similarly, average benthic respiration was $18.1 \mathrm{mg} \mathrm{C}$ $\mathrm{m}^{-2} \mathrm{~h}^{-1}$.

Net production, from which gross production estimates were obtained, was calculated assuming a PQ of 1.2 (Strickland \& Parsons 1972). As Williams et al. (1979) have pointed out, actual PQ values for phytoplankton using nitrate are probably higher, which would make estimates presented here of net production and gross production based on a $P Q=1.2$ too high. However, measurements of nutrient concentrations and fluxes in the benthic chambers made concurrently with the oxygen concentration measurements showed 
Table 2. Estimates of benthic respiration, net benthic production (Net P), and gross benthic production (Gross $P$ ), $\mathrm{mg}_{\mathrm{C}} \mathrm{m}^{-2} \mathrm{~h}^{-1}$ $\pm \mathrm{SD}$, at study sites in Onslow Bay, North Carolina

\begin{tabular}{|c|c|c|c|c|}
\hline Site & Date & Respiration & Net $P$ & Gross P \\
\hline 23 mile & 22 Aug 1989 & $22.2 \pm 6.3$ & $17.4 \pm 4.5$ & 39.6 \\
\hline 23 mile & 18 Aug 1989 & $17.5 \pm 7.3$ & $24.2 \pm 12.2$ & 41.7 \\
\hline 23 mile & 16 Aug 1989 & $18.6 \pm 5.9$ & $38.5 \pm 19.7$ & 57.1 \\
\hline 23 mile & 12 Aug 1989 & $21.9 \pm 7.6$ & $-4.8 \pm 1.7$ & 17.1 \\
\hline 5 mile & 4. Aug 1989 & $20.7 \pm 5.6$ & $-8.8 \pm 7.2$ & 11.9 \\
\hline 5 mile & 3 Aug 1989 & $19.2 \pm 2.3$ & $4.5 \pm 6.8^{\circ}$ & $23.7^{\cdots}$ \\
\hline 5 mile & 2 Aug 1989 & $20.1 \pm 6.9$ & $-1.3 \pm 10.8^{\circ}$ & $18.8^{\circ}$ \\
\hline 18 mile & 15 Oct 1988 & $21.3 \pm 9.2$ & $10.6 \pm 3.5$ & 31.9 \\
\hline 18 mile & 14 Oct 1988 & $27.7 \pm 0.6$ & $4.3 \pm 0.8$ & 32.0 \\
\hline 23 mile & 8 Jul 1988 & $28.3 \pm 4.5$ & $21.9 \pm 12.6$ & 50.2 \\
\hline 23 mile & 14 Jun 1988 & $19.2 \pm 4.5$ & $30.9 \pm 5.8$ & 50.1 \\
\hline 23 mile & 13 Jun 1988 & $13.5 \pm 1.5$ & $12.2 \pm 1.9$ & 25.7 \\
\hline 23 mile & 12 Jun 1988 & $17.2 \pm 2.7$ & $8.9 \pm 11.2^{\circ}$ & 26.2 \\
\hline Tugs & 5 Mar 1986 & $2.2 \pm 3.2^{\circ}$ & $3.2 \pm 2.4$ & 5.5 \\
\hline 3 mile & 4 Mar 1986 & $7.8 \pm 4.8$ & $0.5 \pm 1.5^{\circ}$ & $8.3^{\cdots}$ \\
\hline 23 mile & 25 Sep 1985 & $11.8 \pm 3.0$ & $7.1 \pm 8.1^{\circ}$ & $18.9^{\cdots}$ \\
\hline Frying Pan & 9 Sep 1985 & $17.8-$ & $-13.1 \pm 2.8$ & 4.7 \\
\hline Frying Pan & 8 Sep 1985 & $17.6 \pm 1.6$ & $11.2 \pm 0.8$ & 6.4 \\
\hline Frying Pan & 7 Sep 1985 & $14.3-$ & $-2.2 \pm 0.1$ & 12.1 \\
\hline Frying Pan & 6 Sep 1985 & $16.1 \pm 3.2$ & $20.1 \pm 7.2$ & 36.2 \\
\hline Frying Pan & $31 \mathrm{Jul} \quad 1985$ & $23.7 \pm 9.3$ & $32.7 \pm 4.8$ & 56.4 \\
\hline Frying Pan & $30 \mathrm{Jul} \quad 1985$ & $13.2 \pm 10.7^{\circ}$ & $37.9 \pm 10.4$ & 51.1 \\
\hline Frying Pan & $29 \mathrm{Jul} \quad 1985$ & $15.6 \pm 6.5$ & $-2.1 \pm 5.7^{\circ}$ & $13.5^{*}$ \\
\hline 3 mile & 23 Apr 1985 & $15.0 \pm 4.8$ & $2.9 \pm 6.1^{\circ}$ & $17.9^{*}$ \\
\hline Deep & $21 \mathrm{Apr} 1985$ & $20.2 \pm 6.0$ & $-12.4 \pm 5.5$ & 7.8 \\
\hline 23 mile & $19 \mathrm{Apr} 1985$ & $16.5 \pm 4.9$ & $1.2 \pm 1.4^{\circ}$ & $17.7^{\cdots}$ \\
\hline 23 mile & 26 Sep 1984 & $19.0 \pm 3.4$ & $-18.9 \pm 7.6$ & 0.1 \\
\hline 6 mile & 16 Aug 1984 & $31.6 \pm 2.0$ & $17.5 \pm 4.4$ & 49.1 \\
\hline 3 mile & $26 \mathrm{Jul} 1984$ & $23.3 \pm 8.6$ & $-9.3 \pm 10.2^{\circ}$ & 14.0 \\
\hline
\end{tabular}

that ammonium was the main form of inorganic nitrogen present. Initial ammonium concentrations in the benthic chambers averaged $1.04 \mu \mathrm{M}$ for $13 \mathrm{~d}$; nitrate concentrations in Onslow Bay are typically undetectable at temperatures above about $20^{\circ} \mathrm{C}$, although intrusions of slope water can introduce significant amounts of nitrate episodically (Atkinson 1985). Thus, a choice of $P Q=1.2$ in this study is reasonable.

Daily production by benthic microalgae can be estimated from the hourly production values reported above. Actual incubations usually averaged $6.2 \mathrm{~h}$. However, 2 kinds of information suggest that significant benthic production occurred for a longer period of each day than this. First, measurements of light flux to the bottom by quantum sensors showed that $>1 \%$ of surface incident radiation reached the bottom relatively early in the day (before 08:00 h) and late in the day (after 18:00 h). Divers also usually noted good visibility in dives near dawn and dusk. Second, the oxygen concentrations in water samples withdrawn from benthic chambers at the beginning of incubations were frequently higher than the theoretical $100 \%$ saturation concentrations for the corresponding salinity and temperature (Strickland \& Parsons 1972), suggesting early morning oxygen production at the sedimentwater interface. A significant positive relationship between the amount of dissolved oxygen in excess of $100 \%$ saturation at the beginning of an incubation and net benthic production during that incubation was found (Fig. 2). This result indicates that benthic production began before the incubations were started. Thus, the theoretical 'production day' could be as long as $10 \mathrm{~h}$. Gross daily benthic production could therefore average $249 \mathrm{mg} \mathrm{C} \mathrm{m}^{-2}$ over a season that extends from April through October (roughly $210 \mathrm{~d}$ ).

Similarly, daily benthic respiration rates can be estimated. An estimate of sediment respiration based on an average hourly respiration value of $18.1 \mathrm{mg} \mathrm{C} \mathrm{m}^{-2}$ 


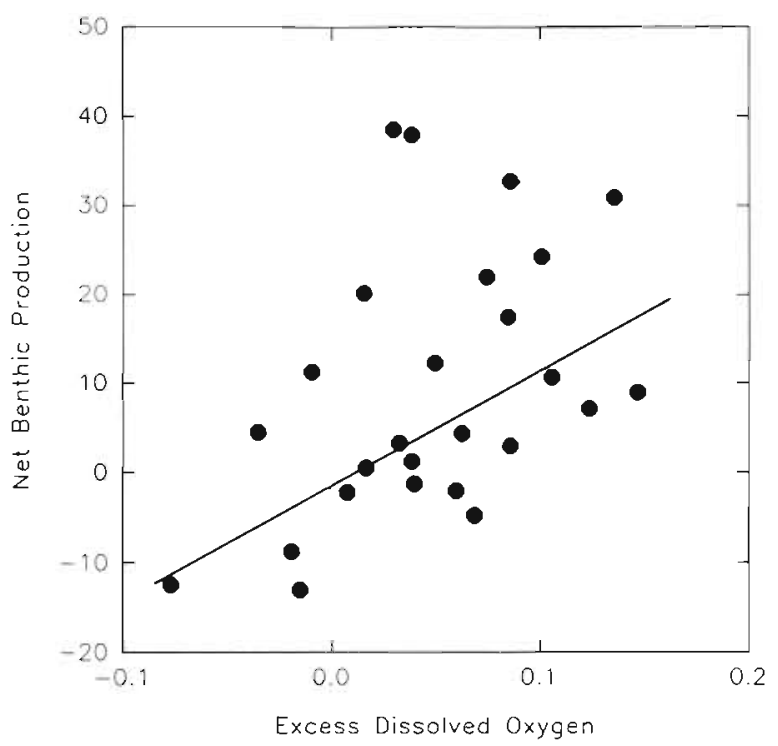

Fig. 2. Regression of net benthic production ( $Y$ ), mg $C$ $\mathrm{m}^{-2} \mathrm{~h}^{-1}$, vs initial dissolved oxygen inside benthic chambers in excess of $100 \%$ saturation level $(X), \mathrm{mmol} \mathrm{l}^{-1}$, at Onslow Bay locations. $Y=0130.1 X-1.91, F=5.42 \mathrm{df}=1,25$, $0.025<\mathrm{p}<0.05, \mathrm{r}^{2}=0.22$

for a $24 \mathrm{~h}$ day yields a value of $434 \mathrm{mg} \mathrm{C} \mathrm{m}^{-2} \mathrm{~d}^{-1}$. Several sources of error introduce potential uncertainty to this estimate. Respiratory rates of microalgae are probably higher in the light than in the dark. Long incubation times might yield elevated respiration rates, although only 2 incubations were longer than 8 h. Migration of significant numbers of demersal zooplankton out of the sediments at night (Tronzo 1989) would lower sediment respiration rates at night.

Primary production by phytoplankton was measured by in situ incubations on 15 of 29 field sampling dates when operational conditions permitted safe handling of radioisotope. Average integrated water column production was $27.4 \mathrm{mg} \mathrm{C} \mathrm{m}^{-2} \mathrm{~h}^{-1}$, and ranged from 2.9 to $71.0 \mathrm{mg} \mathrm{C} \mathrm{m}^{-2} \mathrm{~h}^{-1}$ (Table 3 ). Integrated water column production equalled or exceeded gross benthic production 7 of 15 times, most noticeably in the spring months (March-April). Gross benthic production equalled or exceeded integrated water column production primarily in the summer months, although unusually low production values for both benthic microalgae and phytoplankton in September 1985 should be noted. Average daily phytoplankton production can be estimated as above, assuming a $10 \mathrm{~h}$ day, to be ca $274 \mathrm{mg}$ $\mathrm{C} \mathrm{m}^{-2}$, which is comparable to daily benthic production.

Average benthic microalgal biomass for all locations and times was $36.4 \mathrm{mg} \mathrm{chl} \mathrm{a} \mathrm{m}^{-2}$, and ranged from 17.2 to $62.4 \mathrm{mg}$ chl a m $\mathrm{m}^{-2}$ (Table 4 ). Microscopic observations of sediment samples collected by divers at the study sites indicated that most of the microalgae were
Table 3. Integrated phytoplankton production (Int. P) and gross benthic production (Gross P), mg C m${ }^{-2} \mathrm{~h}^{-1}$, at study sites in Onslow Bay, North Carolina

\begin{tabular}{|c|c|c|c|c|}
\hline Site & Date & & Int. $P$ & Gross P \\
\hline 23 mile & 14 Jun & 1988 & 36.1 & 50.1 \\
\hline 23 mile & 13 Jun & 1988 & 26.1 & 25.7 \\
\hline 23 mile & 12 Jun & 1988 & 36.3 & 26.2 \\
\hline 3 mile & 4 Mar & 1986 & 21.6 & 8.3 \\
\hline 23 mile & $25 \mathrm{Sep}$ & 1985 & 6.3 & 18.9 \\
\hline Frying Pan & 9 Sep & 1985 & 3.4 & 4.7 \\
\hline Frying Pan & 8 Sep & 1985 & 2.9 & 6.4 \\
\hline Frying Pan & 7 Sep & 1985 & 6.6 & 12.1 \\
\hline Frying Pan & $6 \mathrm{Sep}$ & 1985 & 8.1 & 36.2 \\
\hline Frying Pan & $31 \mathrm{Jul}$ & 1985 & 30.8 & 56.4 \\
\hline Frying Pan & $30 \mathrm{Jul}$ & 1985 & 43.7 & 51.1 \\
\hline Frying Pan & $29 \mathrm{Jul}$ & 1985 & 46.1 & 13.5 \\
\hline 3 mile & $23 \mathrm{Apr}$ & 1985 & 47.9 & 17.9 \\
\hline Deep & $21 \mathrm{Apr}$ & 1985 & 71.0 & 7.8 \\
\hline 23 mile & 19 Apr & 1985 & 24.5 & 17.7 \\
\hline
\end{tabular}

Table 4. Benthic microalgal biomass ( $\mathrm{B}$ chl a), $\mathrm{mg}$ chl a $\mathrm{m}^{-2} \pm$ $\mathrm{SD}$, and integrated phytoplankton biomass (W chl a), $\mathrm{mg}$ chl a $\mathrm{m}^{-2}$ at study sites in Onslow Bay, North Carolina. B chl a measured by the spectrophotometric method of Whitney \& Darley (1979); $W$ chl a measured by the fluorometric method of Parsons et al. (1984); -: no data taken

\begin{tabular}{|c|c|c|c|}
\hline Site & Date & B chl a & $W$ chl a \\
\hline 23 mile & 22 Aug 1989 & $47.8 \pm 12.2$ & - \\
\hline 23 mile & 18 Aug 1989 & $36.6 \pm 11.2$ & - \\
\hline 23 mile & 16 Aug 1989 & $35.9 \pm 7.0$ & - \\
\hline 23 mile & 12 Aug 1989 & $39.9 \pm 6.6$ & - \\
\hline 5 mile & 4 Aug 1989 & $16.5 \pm 6.4$ & - \\
\hline 5 mile & 3 Aug 1989 & $35.1 \pm 14.6$ & - \\
\hline 5 mile & 2 Aug 1989 & $17.2 \pm 8.5$ & - \\
\hline 18 mile & 15 Oct 1988 & $36.6 \pm 9.5$ & - \\
\hline 18 mile & 14 Oct 1988 & $47.2 \pm 11.3$ & - \\
\hline 23 mile & 14 Jun 1988 & $30.4 \pm 15.8$ & 4.6 \\
\hline 23 mile & 13 Jun 1988 & $35.0 \pm 5.8$ & 5.9 \\
\hline 23 mile & 12 Jun 1988 & $24.5 \pm 5.9$ & 6.5 \\
\hline Tugs & 5 Mar 1986 & $37.8 \pm 15.2$ & 17.4 \\
\hline 3 mile & 4 Mar 1986 & - & 14.5 \\
\hline 23 mile & 25 Sep 1985 & - & 6.7 \\
\hline Frying Pan & 9 Sep 1985 & - & 12.8 \\
\hline Frying Pan & 8 Sep 1985 & - & 7.5 \\
\hline Frying Pan & 7 Sep 1985 & - & 14.4 \\
\hline Frying Pan & 6 Sep 1985 & - & 2.9 \\
\hline Frying Pan & $31 \mathrm{Jul} 1985$ & - & 5.3 \\
\hline Frying Pan & $30 \mathrm{Jul} 1985$ & - & 3.0 \\
\hline Frying Pan & 29 Jul 1985 & - & 2.9 \\
\hline 3 mile & 23 Apr 1985 & $54.2 \pm 5.5$ & 7.0 \\
\hline Deep & 21 Apr 1985 & $25.1 \pm 13.1$ & 11.0 \\
\hline 23 mile & 19 Apr 1985 & $62.4 \pm 21.4$ & 3.1 \\
\hline
\end{tabular}


pennate diatoms. This would account for the golden brown color commonly observed in the sediment surface (Cahoon et al. 1990). Detailed taxonomic surveys of the diatom flora from Onslow Bay have identified at least 147 species, including over 100 pennate species, of which the majority were biraphic forms (L. B. Cahoon \& R. A. Laws unpubl.). The Deep location differed in that microalgae at the sediment-water interface appeared green and filamentous, suggesting dominance by chlorophytes or cyanobacteria.

Integrated phytoplankton biomass averaged $8.2 \mathrm{mg}$ chl $a \mathrm{~m}^{-2}$ and ranged from 2.9 to $17.4 \mathrm{mg} \mathrm{chl} \mathrm{a} \mathrm{m} \mathrm{m}^{-2}$ (Table 4). These values were always lower than benthic chl a levels when the 2 parameters were measured simultaneously, with more than $80 \%$ of the total chlorophyll $a$ associated with the sediment-water interface. Benthic chl a was measured by a more conservative method (Whitney \& Darley 1979) than water column chl a (Parsons et al. 1984), so $80 \%$ may be an underestimate of the relative benthic chlorophyll a concentration.

Calculation of assimilation numbers (production per unit biomass per unit time) showed that phytoplankton were much more productive relative to benthic microalgae on average. Assimilation numbers for phytoplankton averaged $5.20 \mathrm{mg} \mathrm{C}(\mathrm{mg} \mathrm{chl} \mathrm{a})^{-1} \mathrm{~h}^{-1}$ and ranged from 0.27 to 15.90 (Table 5). In contrast, assimilation numbers for benthic microalgae averaged 0.80 $\mathrm{mg} \mathrm{C}(\mathrm{mg} \mathrm{chl} \mathrm{a})^{-1} \mathrm{~h}^{-1}$, ranging from 0.15 to 1.65 . Assimilation numbers for phytoplankton were especially low for September 1985, suggesting a late summer period of nutrient limitation. Assimilation numbers for benthic microalgae were particularly low in the spring months (March-April).

The data reported here do not completely quantify the relationship between probable limiting factors and benthic microalgal production. A plot of gross benthic production against light extinction coefficients shows that high light extinction coefficients correspond to lower production (Fig. 3). A linear regression of gross benthic production against benthic microalgal biomass was not significant ( $F=0.09$, df $=1,14, p \Rightarrow 0.05$ ). Regression of gross production against temperature was not significant $(F=2.95$, df $=1,26, p>0.05)$. Regression of respiration against temperature was significant $\left(F=10.71\right.$, df $\left.=1,26, p<0.005, r^{2}=0.29\right)$, but only because of 2 measurements (out of 29) taken at low temperature (Tables 1 \& 2).

More anecdotal observations suggest roles for light, temperature, and nutrient limitation of benthic microalgal production. Benthic production on cloudy days, e.g. 12 Aug 1989 and 29 Jul 1985, was noticeably lower than production on subsequent days at the same locations and depths (Table 2). All values of gross production at times when temperatures were less than $20^{\circ} \mathrm{C}$
Table 5. Assimilation numbers, in $\mathrm{mg} C(\mathrm{mg} \mathrm{chl} \mathrm{a)})^{-1} h^{-1}$, for integrated phytoplankton ( $\mathrm{P}$ assim) and benthic microalgae (B assim.) at study sites in Onslow Bay, North Carolina, -: no data taken

\begin{tabular}{|lccc|}
\hline Site & Date & P assim. & B assim. \\
\hline 23 mile & 22 Aug 1989 & - & 0.83 \\
23 mile & 18 Aug 1989 & - & 1.14 \\
23 mile & 16 Aug 1989 & - & 1.59 \\
23 mile & 12 Aug 1989 & - & 0.43 \\
5 mile & 4 Aug 1989 & - & 0.72 \\
5 mile & 3 Aug 1989 & - & 0.68 \\
5 mile & 2 Aug 1989 & - & 1.25 \\
18 mile & 15 Oct 1988 & - & 0.87 \\
18 mile & 14 Oct 1988 & - & 0.68 \\
23 mile & 14 Jun 1988 & 7.85 & 1.65 \\
23 mile & 13 Jun 1988 & 4.42 & 0.74 \\
23 mile & 12 Jun 1988 & 5.58 & 1.07 \\
Tugs & 5 Mar 86 & - & 0.15 \\
3 mile & 4 Mar 86 & 1.49 & - \\
23 mile & 25 Sep 1985 & 0.94 & - \\
Frying Pan & 9 Sep 1985 & 0.27 & - \\
Frying Pan & 8 Sep 1985 & 0.39 & - \\
Frying Pan & 7 Sep 1985 & 0.46 & - \\
Frying Pan & 6 Sep 1985 & 2.79 & - \\
Frying Pan & 31 Jul 1985 & 5.81 & - \\
Frying Pan & 30 Jul 1985 & 14.5 & - \\
Frying Pan & 29 Jul 1985 & 15.9 & - \\
3 mile & 23 Apr 1985 & 6.84 & 0.33 \\
Deep & 21 Apr 1985 & 6.45 & 0.31 \\
23 mile & 19 Apr 1985 & 7.90 & 0.28 \\
\hline
\end{tabular}

were also lower than the maximal production values observed in the summer (Tables $1 \& 2$ ). Divers frequently noted dense patches of benthic microalgae clustered around polychaete worm burrows and other possible nutrient sources.

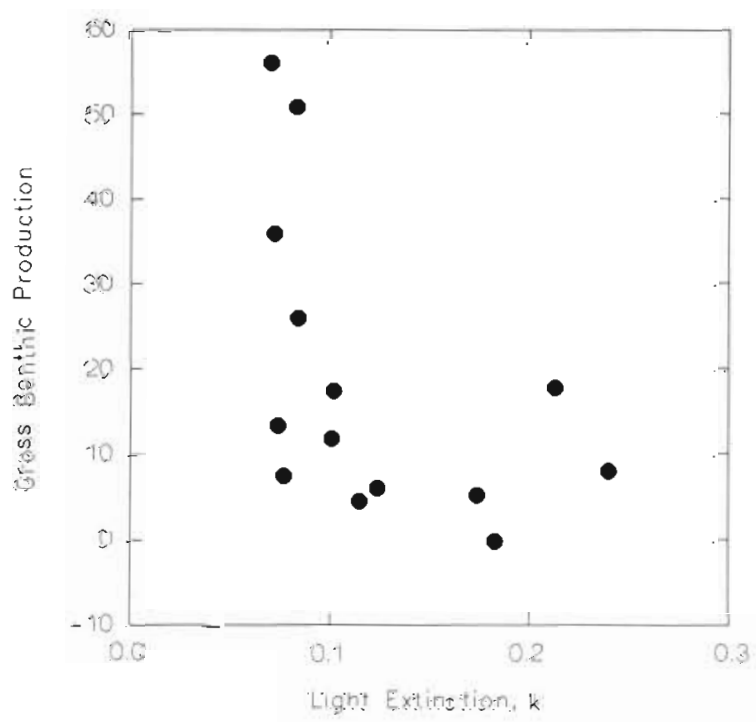

Fig. 3. Gross benthic production, $\mathrm{mg} C \mathrm{~m}^{-2} \mathrm{~h}-$, vs light extinction coefficient, $k_{f}$ at Onslow Bay stations 


\section{DISCUSSION}

Benthic microalgal production rates reported here are the first such data from an open continental shelf habitat and temperate waters, and are quite significant in comparison to production rates reported from other subtidal habitats. Average gross benthic microalgal production in Onslow Bay for all times and sites was $24.9 \mathrm{mg} \mathrm{C} \mathrm{m}^{-2} \mathrm{~h}^{-1}$ and $\mathrm{ca} 52 \mathrm{~g} \mathrm{C} \mathrm{m}^{-2} \mathrm{yr}^{-1}$. Gargas (1970) reported values of 125 to $300 \mathrm{mg} \mathrm{C} \mathrm{m}^{-2} \mathrm{~h}^{-1}$ from the much shallower Danish Øresund. Horner \& Schrader (1982) reported virtually negligible production by benthic microalgae from the Beaufort Sea, but Matheke \& Horner (1974) had previously reported benthic microalgal production rates of 0.5 to $57 \mathrm{mg} \mathrm{C}$ $\mathrm{m}^{-2} \mathrm{~h}^{-1}$ in the nearshore Chukchi Sea, which corresponded to ca $5 \mathrm{~g} \mathrm{C} \mathrm{m}^{-2} \mathrm{yr}^{-1}$ in the short polar growing season. Bunt et al. (1972) report relatively low values of 2.5 to $13.8 \mathrm{mg} \mathrm{C} \mathrm{m}^{-2} \mathrm{~h}^{-1}$ from calcareous sand habitats in the Caribbean and off Florida, but Sournia (1976) measured benthic production rates of 72 to $221 \mathrm{mg} \mathrm{C}$ $\mathrm{m}^{-2} \mathrm{~h}^{-1}$ (after converting his oxygen data to $\mathrm{C}$ production by Eq. 1) in similar tropical habitats. However, Sournia's higher rates of production were measured in relatively shallow waters $(<17 \mathrm{~m})$, whereas the values reported here from Onslow Bay came from an average depth of $26.4 \mathrm{~m}$.

The benthic microalgal production rates reported here are also comparable to rates reported from some intertidal and estuarine habitats, which is surprising in view of the significantly greater exposure to light offered microalgae in these habitats. Cadee \& Hegeman (1974) reported annual benthic productivity in the range of $100 \mathrm{~g} \mathrm{C} \mathrm{m}^{-2} \mathrm{yr}^{-1}$ in the Dutch Wadden Sea. Steele \& Baird (1968) found relatively low productivity, 4 to $9 \mathrm{~g} \mathrm{C} \mathrm{m}^{-2} \mathrm{yr}^{-1}$, on a Scottish beach. Varela \& Penas (1985) reported an annual benthic productivity of $79 \mathrm{~g}$ $\mathrm{C} \mathrm{m}^{-2}$ in a Spanish estuary. Others have reported significantly higher annual productivity values from estuarine and intertidal habitats, e.g. $200 \mathrm{~g} \mathrm{C} \mathrm{m}^{-2} \mathrm{yr}^{-1}$ in a Georgia salt marsh (Pomeroy 1959), $105.5 \mathrm{~g} \mathrm{C} \mathrm{m}^{-2}$ $\mathrm{yr}^{-1}$ in a salt marsh near Woods Hole, Massachusetts (Van Raalte et al. 1976), and rates of 571 to $892 \mathrm{~g} \mathrm{C} \mathrm{m}^{-2}$ $\mathrm{yr}^{-1}$ in the Danish Wadden Sea (Grøntved 1962).

Average benthic microalgal production is approximately equal to average integrated phytoplankton production in Onslow Bay, although there are several aspects to the comparison. Benthic microalgal production equals or exceeds integrated phytoplankton production primarily in the summer months, when light flux to the bottom is generally higher than at other times of the year and integrated phytoplankton biomass is generally relatively lower (Tables $1 \& 4$ ). Phytoplankton production values reported here (Table 3 ) are similar to values reported by others for Onslow Bay and adjacent waters of the $\mathrm{SAB}$, e.g. $21.3 \mathrm{mg} \mathrm{C} \mathrm{m}^{-2} \mathrm{~h}^{-1}$ in August (Smith \& Barber 1974) and $11.9 \mathrm{mg} \mathrm{C} \mathrm{m}^{-2} \mathrm{~h}^{-1}$ for December (Smith \& Cowles 1975). However, phytoplankton production in Onslow Bay is likely to respond strongly to temporal pulses of nutrients from storm events and from intrusions of slope water following upwelling events at the shelf break (Atkinson 1985. Yoder 1985). The relatively infrequent sampling of phytoplankton production in the effort described here and necessary lack of field work during storm events make it likely that an average of the integrated phytoplankton production values reported here is an underestimate. Also, the ${ }^{14} \mathrm{C}$ method probably underestimates production in comparison to the oxygen exchange method. Estimates of annual production in outer shelf waters (40 to $200 \mathrm{~m}$ ) are ca $360 \mathrm{~g} \mathrm{C} \mathrm{m}^{-2} \mathrm{yr}^{-1}$ (Yoder 1985). Haines \& Dunstan (1975) estimated annual production in inner shelf water $(0$ to $20 \mathrm{~m})$ to be $285 \mathrm{~g} \mathrm{C} \mathrm{m}^{-2} \mathrm{yr}^{-1}$, but most of the work done in the present study was in the mid-shelf region (20 to $40 \mathrm{~m}$ ), from which fewer measurements of primary production are available from other sources. Several studies elsewhere in the $\mathrm{SAB}$ suggest that mid-shelf production rates are lower than those for the inner shelf or outer shelf areas (Atkinson 1975, 1976, Tenore et al. 1978, Hanson et al. 1981). If production patterns in Onslow Bay are similar to those elsewhere in the SAB, then benthic microalgal production may be highest where and when phytoplankton production is likely to be lowest, i.e. in the mid-shelf zone in summer. Such a relationship is also suggested by Fig. 3, which shows lower benthic production when light extinction coefficients are high, implying that high phytoplankton concentrations might shade benthic microalgae.

The benthic microalgal biomass values reported here

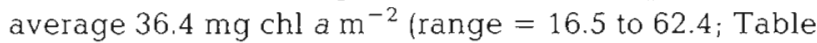
4). These values are virtually identical to those reported by Cahoon et al. (1990) for the corresponding depth intervals in Onslow Bay. These values are also comparable to or somewhat lower than values reported by others for continental shelf sediments, e.g. up to $321 \mathrm{mg} \mathrm{m}^{-2}$ during the brief polar summer in the Chukchi Sea (Matheke \& Horner 1974), and from 23 to $219 \mathrm{mg} \mathrm{m}^{-2}$ in calcareous sediments in the Caribbean Sea and off Florida (Bunt et al. 1972). However, the other studies cited here employed sediment chlorophyll a extraction techniques that were less likely to remove degradation products than the method we used (Whitney \& Darley 1979), so their data may overestimate actual sediment chlorophyll a.

Assimilation numbers ( $\mathrm{mg} C$ fixed ( $\mathrm{mg} c h l a)^{-1} \mathrm{~h}^{-1}$ ] for benthic microalgae in Onslow Bay were much lower than those for phytoplankton when productivity and biomass of these 2 kinds of primary producers were measured concurrently (Table 5), which suggests 
shade adaptation (an increase in cellular pigment content) by benthic microalgae (Falkowski 1981). However, low assimilation numbers have also been reported for benthic microalgae populations in intertidal areas, e.g. 0.6 to 3.0 from the Danish Wadden Sea intertidal (Rasmussen et al. 1983), 0.2 to 3.2 from the Ems Dollard Estuary intertidal (Colijn \& de Jonge 1984), 0.7 to 0.9 from the same habitat (Colijn \& van Buurt 1975 ), and 0.6 to 3.9 in a shallow Danish fjord (Gargas 1980). Gould \& Gallagher (1990) reported relatively low specific growth rates for benthic diatoms in an intertidal habitat in Massachusetts Bay $\left(0.06\right.$ to $\left.0.27 \mathrm{~d}^{-1}\right)$. Converting the average assimilation number found for microalgae in Onslow Bay (0.80) to specific growth rates for $C$ : chl a ratios of 20 to 60 and a $10 \mathrm{~h}$ growth day yields similar specific growth rates of 0.13 to 0.4 . Shade adaptation is unlikely to occur in shallow and intertidal habitats, so other explanations for these relatively low ratios of production to chlorophyll biomass for benthic microalgae in Onslow Bay must be considered. First, not all of the viable chlorophyll a present in sediments is likely to be active at once. Some microalgae are likely to be shaded by overlying sediment and organic material at least temporarily (Fenchel \& Straarup 1971), whether by active migration by motile forms or by disturbance of the sediment. Localized $\mathrm{CO}_{2}$ depletion by actively photosynthesizing microalgae at the sediment-water interface might limit total production (de Jong \& Admiraal 1984). Nutrient availability may at times limit benthic production. Overestimates of sediment chlorophyll $a$, discussed above, might lead to low calculated assimilation numbers from other studies, but we consider the Whitney \& Darley (1979) method we used to be more conservative. Exposure to ultraviolet radiation may also reduce productivity of intertidal microalgae (Cooke 1991), but is almost certainly not a factor for microalgae in continental shelf waters. Finally, biases in the benthic production measurements, such as light attenuation by the clear walls of the chambers, may cause low estimates of actual production.

The benthic microalgal production data reported here have important implications for our understanding of benthic processes in continental shelf ecosystems, and for our assessment of the overall productivity of shelf ecosystems. The conventional view has been that sand bottoms in continental shelf ecosystems are barren, populated thinly by a few consumers. The production data reported here refute that view. Rather, the sediment-water interface in Onslow Bay, and perhaps in other similar shelf habitats, must be viewed as a much more dynamic part of the shelf habitat, with significant microalgal biomass and production concentrated at a 2 dimensional surface, rather than dispersed through a 3dimensional medium. Benthic microalgae may regulate the flux of regenerated nutrients from sediments, par- ticularly when they are abundant and productive. Benthic microalgae may also regulate oxygen flux into the sediments, especially at night, when their respiration contributes to total sediment respiration. This may help drive the nocturnal emigration of demersal zooplankton from shelf sediments, even while benthic microalgae are a food source for at least some of this assemblage and for the benthic meiofauna (Coull et al. 1982, Tronzo 1989). Resuspended microalgae may be a major component of the frequent near-bottom chlorophyll a maxima found in Onslow Bay and elsewhere in the SAB (see discussion in Cahoon et al. 1990), although most of the microalgae appear to be firmly attached to the sediments. It is likely that complete resuspension or removal of microalgae from their substrates can only be effected by very strong storm waves, such as those in hurricanes, as indicated by the elimination of microalgal production at the normally productive 23 mile site for 26 Sep 1984 after Hurricane Diana (Table 2). Thus, benthic microalgal biomass may be relatively stable through time, offering a dependable food source for both deposit feeders and suspension feeders.

We propose that other continental sheif habitats with a combination of depth and light flux sufficient to support growth by easily observable benthic microalgae on hard substrates may also support significant benthic microalgal populations. It is interesting to note that macroalgae have been observed growing to a record depth of $268 \mathrm{~m}$ in tropical waters (Littler et al. 1985). Autotrophic growth at these depths must require physiological adaptations to growth at light intensities well below the $1 \%$ light level. If benthic microalgae also exhibit such physiological adaptations, their contribution to shelf and global primary production could be even more significant.

Acknowledgements. We gratefully acknowledge support from the National Science Foundation (RII 8311 486), UNC Sea Grant (\#R-MG 84-07, \#R-MG 85-01, and R-MRR-88-01), the UNCW Faculty Research and Development Fund, the North Carolina Board of Science and Technology, and, especially, the National Undersea Research Center at UNC Wilmington (NOAAINURC \#NA80AA-H-00081 and \#NA88AA-DUR004). We thank 3 anonymous reviewers, the crew of RV 'Seahawk', Alan Hulbert, Don Freeman, Craig Tronzo, Charles Amsler, George Simmons, Paulette Peckol, James Finlay, and members of the NURC-UNCW dive team, especially Pat Webster. This is contribution \#045 of the Center for Marine Science Research at UNC Wilmington.

\section{LITERATURE CITED}

Atkinson, L. P. (1975). Oceanographic observations in the Georgia Bight: Data report for R.V. EASTWARD cruises E13-73 (4-11 September) and E-19-73 18-9 December 1973). Ga. Mar. Sci. Cen. Tech. Rep Ser 75-6, Univ. of Georgia, Arhens

Atkinson, L. P. (1976). Oceanographic observations in the 
Georgia Bight: Data report for R.V EASTWARD cruises E3-74 (24-30 April 1974) and E-12-74 (23-31 July 1974). Ga. Mar Sci. Cen. Tech. Rept. Ser. 76-1, Univ. of Georgia, Arhens

Atkinson, L. P. (1985). Hydrography and nutrients of the southeastern U.S. continental shelf. In: Atkinson, L. P.. Menzel, D. W., Bush, K. A. (eds.) Oceanography of the southeastern U.S. continental shelf. American Geophysical Union, Washington, D.C., p. 77-92

A.tkinson, L. P., Blanton, J. O., Haines, E. (1978). Shelf flushing rates based on the distribution of salinity and freshwater in the Georgia Bight. Estuar coast. Mar Sci. 7. 465-472

Atkinson, L. P., Singer, J. J., Pietrafesa, L. J. (1980). Volume of summer subsurface intrusions into Onslow Bay, North Carolina. Deep Sea Res. 27: 421-434

Blanton, J. O., Atkinson, L. P., Pietrafesa, L. J., Lee, T N. (1981). The intrusion of Gulf Stream water across the continental shelf due to topographically-induced upwelling. Deep Sea Res. 28: 393-405

Blanton, J. O., Pietrafesa, L. J. (1978). Flushing of the continental shelt south of Cape Hatteras by the Gulf Stream. Geophys. Res. Lett. 5: 495-498

Bunt, J. S., Lee, C. C., Lee, E. (1972). Primary productivity and related data from tropical and subtropical marine sediments. Mar Biol. 16: 28-36

Cadee, G. C., Hegeman, J. (1974). Primary production of the benthic microflora living on tidal flats in the Dutch Wadden Sea. Neth. J. Sea Res. 8: 260-291

Cadee, G. C., Hegeman, J. (1977). Distribution of primary production of the benthic microflora and accumulation of organic matter on a tidal flat area, Balgzand, Dutch Wadden Sea. Neth. J. Sea Res. 11: 24-41

Cahoon, L. B. (1988). The use of whirling cup rotors to stir benthic chambers. Hydrobiologia 160: 193-198

Cahoon, L. B., Redman, R. S., Tronzo, C. R. (1990). Benthic microalgal biomass in sediments of Onslow Bay, North Carolina. Estuar coast. Shelf Sci. 31: 805-816

Colijn, F., de Jonge, V N. (1984). Primary production of microphytobenthos in the Ems-Dollard estuary. Mar. Ecol. Prog. Ser. 14: 185-196

Colijn, F., van Buurt, G. (1975). Influence of light and temperature on the photosynthetic rate of marine benthic diatoms. Mar. Biol. 31. 209-214

Cooke, J. E. (1991). The effects of ultraviolet radiation $B$ on the diatom Nitzschia closterium. M.Sc. thesis, Univ. of N Carolina at Wilmington

Coull, B. C., Zo, Z., Tietjen, J. H., Williams, B. S. (1982) Meiofauna of the southeastern United States continental shelf. Bull. mar. Sci. 32: 139-150

de Jong. L., Admiraal, W (1984). Competition between three estuarine benthic diatom species in mixed cultures. Mar Ecol. Prog. Ser. 18: 269-275

Falkowski, P. G. (1981). Light-shade adaptation and assimilation numbers. J. Plankton Res. 3: 203-216

Fenchel, T., Straarup, B. J. (1971). Vertical distribution of photosynthetic pigments and the penetration of light in marine sediments. Oikos 22: 172-182

Gargas, E. (1970). Measurements of primary productivity. dark fixation and vertical distribution of the microbenthic algae in the Øresund. Ophelia 8: 231-253

Gargas, E. (1980). Production and photosynthetic efficiency of microalgae (phytoplankton and microbenthos) in a shallow Danish fjord. Vatten 36: 125-138

Gould, D. M., Gallagher, E. D. (1990). Field measurement of specific growth rate, biomass, and prumary production of benthic diatoms of Savin Hill Cove, Boston. Limnol. Oceanogr 35: 1757-1770
Grontved, J. (1962). Preliminary report on productivity of microbenthos and phytoplankton in the Danish Wadden Sea. Meddr Danm. Fisk.-og Havunders. 3: 347-378

Haines, E. B., Dunstan, W M. (1975). The distribution and relation of particulate organic material and primary productivity in the Georgia Bight 1973-1974. Estuar. coast. mar Sci. 3: 431-441

Hanson, R. B., Tenore, K. R., Bishop, S., Chamberlain, C., Pamatmat, M. M., Tietjen, J. (1981). Benthic enrichment in the Georgia Bight related to Gulf Stream intrusions and estuarine outwelling. J. mar Res. 39: 417-441

Hargrave, B. T., Prouse, N. J., Phillips, G. A., Neame, P. A. (1983). Primary production and respiration in pelagic and benthic communities at two intertidal sites in the upper Bay of Fundy. Can. J. Fish. Aquat. Sci. 40 (Suppl. 1): 229-243

Horner, R., Schrader, G. C. (1982). Relative contributions of ice algae, phytoplankton, and benthic microalgae to primary production in nearshore regions of the Beaufort Sea. Arctic 35: 485-503

Hustedt, F. (1955). Marine littoral diatoms of Beaufort, North Carolina. Duke Univ. mar. Station Bull. 6: 1-67

Littler, M., Littler, D., Blair, S. M., Norris, J. N. (1985). Deepest known plant life discovered on an uncharted seamount. Science 227: $57-59$

Lukatelich, R. J., McComb, A. J. (1986). Distribution and abundance of benthic microalgae in a shallow southwestern Australian estuarine system. Mar Ecol. Prog. Ser 27: $287-297$

Matheke, G. E. M., Horner, R. (1974). Primary productivity of the benthic microalgae in the Chukchi Sea near Barrow, Alaska. J. Fish. Res. Bd Can. 31: 1279-1286

Menzies, R. J., Pilkey, O. H., Blackwelder, B. W., Dexter, D. Huling, P., McCloskey, L. (1966). A submerged reef off North Carolina. Int. Revue ges. Hydrobiol. 51. 393-431

Paffenhofer, G.-A., Diebel, D., Atkinson, L. P., Dunstan, W. M. (1980). The relation of concentration and size distribution of suspended particulate matter to hydrography in Onslow Bay, North Carolina. Deep Sea Res. 27: 435-448

Pamatmat, M. M. (1971). Oxygen consumption by the seabed VI. Seasonal cycle of chemical oxidation and respiration in Puget Sound. Int. Revue ges. Hydrobiol. 56: 769-793

Parsons, T R., Maita, Y., Lalli, C. M. (1984). A manual of chemical and biological methods for seawater analysis. Pergamon Press, New York

Pomeroy, L. R. (1959). Algal productivity in salt marshes of Georgia. Limnol Oceanogr. 4: 386-397

Rasmussen, M. B., Henriksen, K., Jensen, A. (1983). Possible causes of temporal fluctuations in primary production of the microphytobenthos in the Dutch Wadden Sea. Mar Biol. 73: 109-114

Revsbech, N. P., Jorgensen, B. B., Brix, O. (1981). Primary production of benthic microalgae in sediments measured by oxygen microprofile, $\mathrm{H}^{14} \mathrm{CO}_{3}$-fixation, and oxygen exchange methods. Limnol. Oceanogr 26: 717-730

Schneider, C. W. $\{1976\}$. Spatial and temporal distributions of benthic algae on the continental shelf of the Carolinas. Bull. mar Sci. 26: 133-151

Singer, J. J., Atkinson, L. P., Pietrafesa, L. J. (1980). Summertime advection of low salinity surface waters into Onslow Bay. Estuar coast. mar. Sci. 11: 73-82

Smith, W O., Barber, R. T (1974). Reduced data report for EASTWARD cruise E-13-74, Cooperative Oceanographic Program. Duke Univ. Marine Laboratory, Beaufort

Smith, W. O., Cowles, T. J. (1975). Reduced data report for R/V EASTWARD cruise E-17-74. Cooperative Oceanographic Program. Duke Univ. Marine Laboratory, Beaufort 
Sournia, A. (1976). Primary production of sands in the lagoon of an atoll, and the role of foraminiferan symbionts. Mar. Biol. 37: 29-32

Steele, J. H., Baird, J. E. (1968). Production ecology of a sandy beach. Limnol. Oceanogr 13: 14-25

Strickland, J. D. H., Parsons, T R. (1972). A practical handbook of seawater analysis. Fisheries Research Board of Canada, Ottawa

Tenore, K. R., Chamberlain, C. F., Dunstan, W. M., Hanson, R. B., Sherr, B., Tietjen, J. (1978). Possible effects of Gulf Stream intrusions and coastal runoff on the benthos of the continental shelf of the Georgia Bight. In: Wiley, $M$. (ed.) Estuarine interactions. Academic Press, New York, p. $577-598$

Tronzo, C. R. (1989). The ecology of demersal zooplankton in Onslow Bay, North Carolina. M.Sc. thesis, Univ. of $N$. Carolina at Wilmington

This article was submitted to the editor
Van Raalte, C. D., Valiela, I., Teal, J. M. (1976). Production of epibenthic salt marsh algae: light and nutrient limitation. Limnol. Oceanogr. 21.862-872

Varela, M., Penas, E. (1985). Primary production of benthic microalgae in an intertidal sand flat of the Ria de Arosa, Spain. Mar. Ecol. Prog. Ser. 25: 111-119

Whitney, D. E., Darley, W. M. (1979). A method for the determination of chlorophyll a in samples containing degradation products. Limnol. Oceanogr. 24: 183-186

Williams, P. J. LeB., Raine, R. C. T., Bryan, J. R. (1979). Agreement between the ${ }^{14} \mathrm{C}$ and oxygen methods of measuring phytoplankton production: reassessment of the photosynthetic quotient. Oceanol. Acta 2: 411-416

Yoder, J. A. (1985). Environmental control of phytoplankton production on the southeastern U.S. continental shelf. In: Atkinson, L. P., Menzel, D. W., Bush, K. A. (eds.) American Geophysical Union, Washington, D.C., p. 93-103

Manuscript first received: January 20, 1992

Revised version accepted: May 12, 1992 